\begin{tabular}{|c|c|c|c|c|}
\hline Prosiding & e ISSN : 2581- & & & \\
Penelitian \& & Vol 6, No: 2 & Hal: $123-180$ & Juli 2019 \\
$\begin{array}{c}\text { Pengabdian } \\
\text { Kepada }\end{array}$ & 2426 p ISSN : & & & \\
Masyarakat & & & & \\
\hline
\end{tabular}

\title{
PENURUNAN PRESTASI BELAJAR REMAJA PADA KELUARGA TKW DI DESA JUNTINYUAT INDRAMAYU
}

\author{
Meiliani Puji Suharto', Sahadi Humaedi ${ }^{2}$ \\ ${ }^{1,2}$ Program Studi IImu Kesejahteraan Sosial Universitas Padjadjaran \\ meiliani97@gmail.com; sahadi.humaedi@unpad.ac.id
}

\begin{abstract}
ABSTRAK
Pengiriman Tenaga Kerja Indonesia ke luar negeri terus mengalami peningkatan guna meningkatkan perekonomian. Kabupaten Indramayu merupakah kabupaten pengirim TKI terbanyak di Indonesia. Saat ini para TKI tidak hanya pria saja, namun wanita pun turut berpartisipasi menjadi Tenaga Kerja Wanita (TKW) guna meningkatkan perekonomian keluarga. Ibu yang bekerja sebagai Tenaga Kerja Wanita (TKW) membawa berbagai dampak baik positif maupun negatif, tidak terkecuali bagi keluarga yang ditinggalkan terutama anak yang sudah memasuki usia remaja. Masa remaja sering dianggap sebagai masa yang paling rawan dalam proses kehidupan. Dalam keluarga TKW, ada beberapa fungsi keluarga yang berjalan secara tidak baik, sehingga membuat remaja lebih memilih lingkungan diluar keluarganya yang dapat menyebabkan penurunan pada prestasi belajar anak. Subjek penelitian adalah remaja usia 12 - 18 tahun yang berlatar belakang dari keluarga TKW dan memiliki permasalahan pada penurunan prestasi belajar di Desa Juntinyuat Indramayu. Tujuan dari penelitian adalah untuk mendeskripsikan kehidupan remaja dalam keluarga TKW dan faktor penyebab penurunan prestasi belajar remaja.
\end{abstract}

Kata kunci: Remaja, Keluarga TKW, Prestasi Belajar

\section{Pendahuluan (Introduction)}

Setiap tahun Indonesia melakukan pengiriman Tenaga Kerja Indonesia (TKI) ke berbagai negara Taiwan, Arab Saudi, Malaysia, Singapura, Qatar, baik pengiriman TKI tersebut di sektor formal maupun sektor informal. Pengiriman TKI masih di dominasi oleh kaum wanita daripada laki-laki. Seperti data penempatan TKI yang tercatat pada Badan Nasional Penempatan dan Perlindungan Tenaga Kerja Indonesia (BNP2TKI) yang terhitung sejak tahun 2013 sampai tahun 2017 bahwa TKW masih mendominasi.

Tabel 1.1

Tabel Penempatan Tenaga Kerja Indonesia Tahun 2013 - 2017

\begin{tabular}{|c|c|c|}
\hline Tahun & Laki-Laki & $\begin{array}{c}\text { Perempua } \\
\text { n }\end{array}$ \\
\hline 2013 & 235.17 & 276.998 \\
\hline 2014 & 186.243 & 243.629 \\
\hline 2015 & 108.965 & 166.771 \\
\hline
\end{tabular}

\begin{tabular}{|l|r|r|}
\hline 2016 & 89.059 & 145.392 \\
\hline 2017 & 78.259 & 183.561 \\
\hline \multicolumn{3}{|c|}{ (Sumber: BNP2TKI) }
\end{tabular}

Beberapa faktor yang mempengaruhi wanita, terutama wanita yang sudah menjadi seorang ibu pergi ke luar negeri untuk menjadi TKW yaitu keinginan untuk memiliki gaya hidup mewah, terlilit hutang, meningkatkan kesejahteraan ekonomi keluarga dari kehidupan sebelumnya, sumber perekonomian di desa seperti pertanian dan perikanan tidak dapat mencukupi kebutuhan sehari-hari hingga kekerasan dalam rumah tangga (KDRT). Terbatasnya keterampilan yang dimiliki membuat sebagian wanita turut berpartisipasi dalam mencapai kesejahteraan keluarganya dengan memilih bekerja sebagai TKW di luar negeri. Minimnya pendidikan pun turut mendorong para ibu untuk menjadi 


\begin{tabular}{|c|c|c|c|c|}
\hline Prosiding & e ISSN : 2581- & & & \\
Penelitian \& & Vol 6, No: 2 & Hal: $123-180$ & Juli 2019 \\
$\begin{array}{c}\text { Pengabdian } \\
\text { Kepada }\end{array}$ & 1126 p ISSN : & 2442-448X & & \\
Masyarakat & & & \\
\hline
\end{tabular}

TKW tanpa harus pikir panjang akan resiko yang akan ditimbulkan bagi keluarganya.

Jawa Barat menjadi salah satu provinsi yang melakukan pengiriman TKI terbesar di Indonesia. Daerah yang menjadi pemasok TKW terbanyak di Jawa Barat adalah Kabupaten Indramayu yang menempati posisi pertama di Indonesia dalam pengiriman TKW ke luar negeri pada tahun 2017. Berikut merupakan lima kota/ kabupaten yang ada di Indonesia yang diperoleh dari Dinas Ketenagakerjaan Kabupaten Indramayu.

Tabel 1.2.

Data Penempatan TKI Berdasarkan Kabupaten/Kota Tahun 2017

\begin{tabular}{|c|l|c|c|c|c|}
\hline \multirow{2}{*}{ No } & \multirow{2}{*}{$\begin{array}{c}\text { Daerah } \\
\text { Asal }\end{array}$} & $\begin{array}{c}\text { Forma } \\
\text { I }\end{array}$ & $\begin{array}{c}\text { Informa } \\
\text { I }\end{array}$ & Jumlah & \\
\hline 1 & $\begin{array}{l}\text { Indramay } \\
\text { u }\end{array}$ & 13.568 & 4.090 & 17.658 & 8,3 \\
\hline 2 & $\begin{array}{l}\text { Lombok } \\
\text { Timur }\end{array}$ & 857 & 14.475 & 15.332 & 7,2 \\
\hline 3 & Cirebon & 7.242 & 2.943 & 10.185 & 4,8 \\
\hline 4 & Cilacap & 6.983 & 3.194 & 10.177 & 4,8 \\
\hline 5 & $\begin{array}{l}\text { Lombok } \\
\text { Tengah }\end{array}$ & 912 & 8.890 & 9.802 & 4,6 \\
\hline
\end{tabular}

(Sumber: Dinas Ketenagakerjaan

Kabupaten Indramayu, 2017)

Sudah bukan menjadi hal yang tabu lagi bagi masyarakat Indramayu bahwa seorang wanita yang sudah cukup usia untuk bekerja dikirim keluar negeri menjadi TKW. Budaya masyarakat yang sudah seperti turun menurun ditularkan kepada para wanita untuk menjadi TKW di luar negeri karena sudah ada jaminan berupa upah yang besar dan bayangan akan kehidupan masa depan yang lebih baik daripada sekarang.

Pada umunya seorang wanita lebih berorientasi pada bagian internal keluarganya seperti mengurus rumah, menjaga harta keluarga, serta mengasuh dan mendidik anak-anak mereka, sedangkan seorang pria yang seharusnya berada di ranah publik yang bertugas sebagai pelindung keluarga dan pencari nafkah bagi keluarga. Tetapi karena alasan kebutuhan ekonomi, para ibu rumah tangga memutuskan untuk bekerja dengan marantau ke negeri orang dengan bekal tekat untuk merubah nasib dan kehidupannya juga keluarga. Hal itupun turut dirasakan oleh beberapa wanita di Indramayu yang sudah tidak tabu lagi untuk memilih bekerja sebagai TKW di luar negeri.

Pengiriman TKW ke luar negeri ternyata menimbulkan berbagai permasalahan. Tak hanya permasalahan bagi perekonomian, namun juga permasalahan pada keluarga yang ditinggalkan, terutama dampak yang dirasakan oleh anak. Menurut Komisi Perlindungan Anak Indonesia (KPAI), para TKW boleh meninggalkan sang anak setelah anak berusia 12 tahun atau ketika anak-anak sudah beranjak remaja, karena usia tersebut dianggap sebagai usia aman anak karena telah melewati golden age anak (KPAl, 2015). Namun, masa remaja yang merupakan masa yang penting bagi kehidupan anak, yaitu masa peralihan antara masa kanak-kanak ke masa dewasa, mengalami perubahan yang sangat pesat, baik secara fisik, psikis maupun sosial (Hurlock, 2005). Santrock (2012) menjelaskan bahwa masa remaja adalah suatu pergeseran yang terjadi di dalam fase kehidupan individu yang mengaitkan antara masa anak-anak dengan masa dewasa.

Masa remaja merupakan salah satu tahap perkembangan sepanjang rentang kehidupan manusia yang paling unik, penuh dinamika, sekaligus penuh dengan tantangan dan harapan. Pada masa ini terjadi perubahan mendasar, salah satunya perubahan pada aspek kognitif. Pada aspek ini remaja telah mencapai tahap formal oprasional dan remaja mengalami perubahan besar dalam memahami berbagai aspek yang ditemui, menjadi lebih kritis dalam melihat dan memberi respon lingkungannya. Remaja menjadi sangat resisten terhadap berbagai aspek yang tidak masuk di akalnya. Remaja juga telah mampu untuk merumuskan cita-cita masa depannya.

Kondisi internal dan eksternal yang sama-sama bergejolak menyebabkan 


\begin{tabular}{|c|c|c|c|c|}
\hline Prosiding & ISSN : 2581- & Vol 6, No: 2 & Hal: $123-180$ & Juli 2019 \\
$\begin{array}{c}\text { Penelitian \& } \\
\text { Pengabdian }\end{array}$ & 1126 p ISSN: & 2442-448X & & \\
Kepada & & & \\
Masyarakat & & & \\
\hline
\end{tabular}

masa remaja lebih rawan, sehingga perlu diciptakan kondisi lingkungan terdekat yang stabil, khususnya lingkungan keluarga untuk mengurangi benturan gejolak remaja dan untuk memberi kesempatan agar remaja dapat mengembangkan dirinya secara optimal. Menurut Loree (1970) salah satu faktor anak mengalami kesulitan belajar menyangkut Enviromental variables yaitu harmonis tidaknya hubungan manusiawi baik di sekolah, di rumah maupun di lingkungan masyarakat. Hal tersebut belum tentu diperoleh anak pada keluarga TKW. Anak yang dibesarkan dalam keluarga TKW mempunyai resiko lebih besar menghadapi gejolak sosial. Apalagi remaja yang memasuki usia remaja, mereka harus bisa menyeimbangkan antara kehidupan di rumah dan di sekolah.

Usia remaja yang rawan didukung dengan ketidakhadiran orang tua bisa memicu anak mengalami kesulitan belajar. Apabila remaja gagal dalam mengembangkan kemampuannya, maka anak akan kehilangan arah bagaikan kapal yang kehilangan kompas. Pergaulan dengan teman sebaya tentu akan berdampak kepada bagaimana remaja menempatkan diri di lingkungan sosialnya. Pertemanan yang baik tentu akan menghasilkan perilaku yang baik dan sebaliknya. Namun yang terjadi belakangan ini, banyak diantara remaja yang salah memilih pergaulan dengan teman sebayanya sehingga hal tersebut berdampak negatif bagi remaja, salah satunya adalah kemunduran pada prestasi belajar remaja.

Penelitian Puspitawati, $\mathrm{H}$ dan Sherly S.S (2011) menyimpulkan bahwa "prestasi anak dari TKW termasuk dalam kategori cukup dengan rata-rata nilai sebesar 66,7". Berdasarkan karakteristik keluarga, persentase terbesar suami $(51,06 \%)$ dan istri $(85,11 \%)$ memiliki pendidikan tamat sekolah dasar. Berdasarkan interaksi dalam keluarga, lebih dari separuh $(59,57 \%)$ keluarga TKW memiliki interaksi antara ibu dan anak dalam kategori sedang, dengan komunikasi $(63,83 \%)$ dan emotional bonding $(59,57 \%)$ pada tingkat sedang.
Penelitian Utari, N (2015) menyimpulkan bahwa "dukungan sosial orang tua dan motivasi prestasi mempunyai pengaruh pada prestasi belajar sebesar $18 \%$, sedangkan $82 \%$ dipengaruhi oleh faktor internal dan eksternal dari individu. Blood, diacu dalam Luthfiyasari (2004) menyebutkan beberapa akibat yang mungkin terjadi dari keterpisahan anggota keluarga dan perubahan keberfungsian keluarga antara lain berkurangnya intensitas komunikasi, melemahnya ikatan kekerabatan, goyahnya stabilitas keluarga, serta melonggarnya keterikatan moral terhadap budaya setempat.

Menurut Muhibbin Syah (2013) ada tiga faktor yang memengaruhi belajar, yaitu faktor internal, faktor eksternal, dan faktor pendekatan belajar. Faktor internal merupakan faktor dari dalam siswa yakni keadaan atau kondisi jasmani dan rohani siswa. Faktor eksternal merupakan faktor dari luar yakni kondisi lingkungan di sekitar siswa. Faktor pendekatan belajar yakni jenis upaya belajar siswa yang meliputi strategi dan metode yang digunakan siswa untuk melakukan kegiatan mempelajari materi-materi pelajaran. Hal yang menyebabkan adanya prestasi belajar yang rendah (underachieves) karena seorang siswa bersikap conserving terhadap ilmu pengetahuan atau bermotif ekstrinsik (faktor eksternal) serta tidak mendapat dukungan positif dari orangtua sehingga mereka cenderung mengambil pendekatan belajar yang sederhana.

Tujuan dari penulisan artikel ini adalah untuk mendeskripsikan kehidupan remaja dalam keluarga TKW dan faktor penyebab penurunan prestasi belajar remaja.

\section{METODE PENELITIAN}

Penelitian ini menggunakan studi literatur sebagai data sekunder. Penggunaan studi literature ini dipilih peneliti untuk mengeksplorasi dan memahami tentang bagaimana penurunan prestasi belajar pada remaja dari keluarga TKW. Remaja yang dimaksud disini adalah anak pada usia 12-18 tahun. 


\begin{tabular}{|c|c|c|c|c|}
\hline Prosiding & e ISSN : 2581- & & & \\
Penelitian \& & Vol 6, No: 2 & Hal: $123-180$ & Juli 2019 \\
$\begin{array}{c}\text { Pengabdian } \\
\text { Kepada }\end{array}$ & $2442-448$ ISSN : & & & \\
Masyarakat & & & \\
\hline
\end{tabular}

Dalam melakukan penelitian ini harus dilakukan teknik penyusunan yang sistematis untuk memudahkan langkahlangkah yang akan diambil. Begitu pula yang dilakukan penulis dalam penelitian ini, langkah pertama yaitu dengan melakukan studi literatur pada jurnal dan buku mengenai TKW dan permasalahan prestasi belajar pada remaja. Literatur mengenai undang-undang yang berkaitan dengan permasalahan dalam penelitian ini pun dapat digunakan sebagai mendukung pengetahuan permasalahan yang diangkat dalam artikel ini. Selanjutnya yaitu dengan menganalisis data-data yang didapat.

Lokasi studi kasus ini dilaksanakan pada di Desa Juntinyuat Kabupaten Indramayu dimana daerah tersebut merupakan daerah pemasok TKW terbesar di Indonesia dan rawan terkena berbagai permasalahan ketenagakerjaan termasuk masalah penelantaran pada anak.

\section{KAJIAN PUSTAKA \\ Migrasi dan Faktor-faktor Migrasi Internasional}

1. Pengertian Migrasi

Migrasi merupakan bagian dari mobilitas penduduk. Migrasi adalah mobilitas atau perpindahan penduduk dari suatu tempat ke tempat lain dengan melewati batas negara atau batas administrasi dengan tujuan untuk menetap, sebagaimana pendapat Mantra (2003:172). Migrasi terbagi menjadi dua yatu migrasi ke dalam dan keluar. Dalam hal ini mgrasi yang dimaksud adalah migrasi keluar atau migrasi internasional. Biasanya migrasi internasional berkaitan dengan pengiriman penduduk untuk bekerja di luar negeri atau yang disebut dengan Tenaga Kerja Indonesia (TKI).

Pada Pasal 1 Ayat (2) UndangUndang No. 13 Tahun 2003 tentang Ketenagakerjaan dinyatakan bahwa, "Tenaga kerja adalah setiap orang yang mampu melakukan pekerjaan guna menghasilkan barang atau jasa baik untuk memenuhi kebutuhan sendiri maupun untuk masyarakat". Pengertian tenaga kerja dalam undang-undang tersebut menyempurnakan pengertian tenaga kerja dalam
Undang-Undang Nomor 14 Tahun 1969 Tentang Pokok-Pokok Tenaga Kerja yang memberikan pengertian "Tenaga kerja adalah setiap orang yang mampu melakukan pekerjaan baik di dalam maupun di luar hubungan kerja guna menghasilkan barang atau jasa untuk memenuhi kebutuhan masyarakat".

Berdasarkan Pasal 1 Undang-Undang No. 39 Tahun 2004 tentang Penempatan dan Perlindungan Tenaga Kerja Indonesia di Luar Negeri, “Tenaga Kerja Indonesia adalah setiap warga negara Indonesia yang memenuhi syarat untuk bekerja di luar negeri dalam hubungan kerja untuk jangka waktu tertentu dengan menerima upah".

Berdasarkan pengertian tersebut, maka yang dimaksud dengan Tenaga Kerja Indonesia adalah setiap warga negara Indonesia yang bekerja di luar negeri dalam jangka waktu tertentu berdasarkan perjanjian kerja antara Tenaga Kerja Indonesia dengan Perusahaan Industri yang ada di luar negeri dengan menerima upah.

Dalam artikel ini fokus yang akan dibahas adalah mengenai wanita yang bekerja sebagai Tenaga Kerja Wanita (TKW) di luar negeri.

2. Faktor yang Mempengaruhi Wanita Sebagai Tenaga Kerja Wanita (TKW)

Mustaniroh (2005) mengatakan bahwa wanita bekerja dalam mencurahkan waktunya untuk bekerja dipengaruhi oleh pendapatan dalam keluarga. Ini disebabkan bila pendapatan keluarga dalam hal ini suami kurang memenuhi kebutuhan dalam keluarga maka wanita sebagai isteri dapat membantu suami dalam memenuhi kebutuhan keluarga dengan cara bekerja. Jumlah anggota keluarga merupakan salah satu faktor yang memengaruhi curahan waktu kerja wanita. Terdapat empat faktor yang mempengaruhi seseorang melakukan migrasi yaitu: a) Faktor-faktor yang terdapat di daerah asal (Origin); b) Faktor-faktor yang terdapat di daerah tujuan (destination); c) Penghalang/Rintangan antara daerah asal dan daerah tujuan. 


\begin{tabular}{|c|c|c|c|c|}
\hline Prosiding & e ISSN : 2581- & & & \\
Penelitian \& & Vol 6, No: 2 & Hal: $123-180$ & Juli 2019 \\
$\begin{array}{c}\text { Pengabdian } \\
\text { Kepada }\end{array}$ & 1126 p ISSN : & V442-448X & & \\
Masyarakat & & & \\
\hline
\end{tabular}

\section{Konsep Keluarga}

1. Pengertian Keluarga

Menurut Burgess dan Locke dalam Khairuddin (2008), keluarga merupakan unit terkecil dalam masyarakat yang terdiri dari ayah, ibu dan anak, masingmasing anggota keluarga memiliki peranan, saling berkomunikasi dan berinteraksi satu sama lain dalam melaksanakan peranan tersebut serta menciptakan dan memelihara nilai-nilai serta budaya yang dianut.

Keluarga merupakan sekumpulan orang yang di hubungkan oleh perkawinan, adopsi dan kelahiran yang bertujuan menciptakan dan mempertahankan budaya yang umum, meningkatkan perkembangan fisik, mental, emosional dan social dari individuindividu yang ada di dalamnya terlihat dari pola interaksi yang saling ketergantungan untuk mencapai tujuan bersama (Friedman, 1998). Sedangkan menurut Effendy (1998), keluarga sebagai perkumpulan dua atau lebih dari dua individu yang tergabung karena hubungan darah, hubungan perkawinan atau pengangkatan dan mereka hidup dalam suatu rumah tangga, berinteraksi satu sama lain dan di dalam peranannya masing-masing dan menciptakan serta mempertahankan suatu kebudayaan.

Dari pengertian keluarga diatas penulis dapat menyimpulkan bahwa keluarga adalah seperangkat bagian yang saling tergantung satu sama lain serta memiliki perasaan beridentitas dan berbeda dari anggota dan tugas utama keluarga adalah memelihara kebutuhan psikososial anggota-anggotanya dan kesejahteraan hidupnya secara umum.

2. Fungsi Keluarga

Menurut Ritonga, dkk (1996) fungsi keluarga berkaitan langsung dengan aspek-aspek sebagai berikut:

a. Fungsi ekonomi, untuk kelangsungan hidup suatu keluarga, peranan ekonomi keluarga sangat penting. Hal ini dimaksudkan adalah agar kebutuhan keluarga baik primer, sekunder dapat terpenuhi sesuai kemampuan keluarga yang dimiliki.

b. Fungsi sosialisasi, dalam suatu keluarga peranan sosialisasi sangat penting, karena malalui proses ini setiap individu dapat belajar interaksi dengan anggota kerabat lainnya. Hal ini meliputi nilai, norma dan istiadat.

c. Fungsi perlindungan, keluarga sebagai tempat berlindung, menciptakan ketenangan dan kenyamanan bagi anak.

d. Fungsi reproduksi, keluarga adalah lembaga terkecil dalam masyarakat yang mempunyai fungsi reproduksi yaitu meneruskan dan melanjutkan keturunan keluarga.

\section{Konsep Belajar}

Gronbach

didalam bukunya

Educational Psychology menyatakan bahwa: "Learning is shown by a change in behavior as a result of experience".

Menurut Gronbach belajar yang sebaik-baiknya adalah dengan mengalami; dan di dalam mengalami itu si pelajar mempergunakan pancainderanya (Suryabrata. 2008; 231) Belajar merupakan proses penting bagi perubahan perilaku manusia dan ia mencakup segala sesuatu yang dipikirkan dan dikerjakan (Anni, dkk. 2006; 2). Belajar memegang peranan penting di dalam perkembangan, kebiasaan, sikap, keyakinan, tujuan, kepribadian, dan bahkan persepsi manusia.

Konsep tentang belajar mengandung tiga unsur utama, yaitu:

a. Belajar berkaitan dengan perubahan perilaku. Untuk mengukur apakah seseorang telah belajar, maka diperlukan perbandingan antara perilaku sebelum dan setelah mengalami kegiatan belajar. Perilaku tersebut dapat diwujudkan dalam bentuk perilaku tertentu, seperti menulis, membaca, berhitung yang dilakukan secara sendiri-sendiri, atau kombinasi dari berbagai tindakan.

b. Perubahan perilaku itu terjadi karena didahului oleh proses pengalaman.

c. Perubahan perilaku karena belajar bersifat relatif permanen. Pengertian 


\begin{tabular}{|c|c|c|c|c|}
\hline Prosiding & e ISSN : 2581- & & & \\
Penelitian \& & Vol 6, No: 2 & Hal: $123-180$ & Juli 2019 \\
$\begin{array}{c}\text { Pengabdian } \\
\text { Kepada }\end{array}$ & 1126 p ISSN : & 2442-448X & & \\
Masyarakat & & & \\
\hline
\end{tabular}

belajar adalah berbeda dengan pengertian pertumbuhan dan perkembangan (Shephert dan Ragan dalam Anni. 2006; 4). Pertumbuhan (growth) merupakan karakteristik individu yang diperoleh dari kehidupan. Pada umumnya istilah pertumbuhan digunakan untuk menunjukkan pertambahan jumlah sesuatu. Belajar (learning) mengacu pada perubahan perilaku yang terjadi sebagai akibat dari interaksi antara individu dengan lingkungannya. Apa yang dipelajari oleh seseorang dapat diuraikan dan dapat disimpulkan dari pola-pola perubahan perilakunya. Perkembangan (development) mengacu pada perubahan yang dihasilkan dari kombinasi pengaruh pertumbuhan dan belajar. Perkembangan emosional, misalnya, bukan semata-mata dipengaruhi oleh kematangan fisik, melainkan juga karena faktor belajar.

\section{Faktor-faktor yang Mempengaruhi Belajar}

Belajar sebagai proses atau aktivitas disyaratkan oleh banyak faktor, menurut Suryabrata (2008; 233-235) faktor-faktor tersebut dapat diklasifikasikan sebagai berikut:

1) Faktor-faktor yang berasal dari luar diri pelajar, yang dapat digolongkan lagi dalam dua golongan:

a. Faktor-faktor non-sosial

Faktor-faktor ini tak terhitung jumlahnya, seperti misalnya: keadaan udara, suhu, udara, cuaca, waktu (pagi, siang atau malam), tempat belajar, alat-alat belajar dll.

b. Faktor-faktor sosial

Faktor ini dipengaruhi oleh faktor manusia baik kehadiran langsung maupun tidak langsung. Sebagai contoh, pendampingan belajar orang tua pada anak atau saudara yang hilir mudik pada saat pembelajar sedang belajar dapat menjadi penghambat belajat tersebut.
2) Faktor-faktor yang berasal dari dalam pembelajar, dan juga dapat lagi digolongan menjadi dua yaitu:

a. Faktor Fisiologis

Faktor fisik dari si pembelajar menjadi faktor penting dalam belajar itu sendiri. Kondisi jasmani seseorang mempengaruhi aktivitas belajar. Keadaan jasmani yang sehat akan berbeda dengan kondisi yang tidak sehat sehingga diperlukan nutrisi yang cukup untuk mereka.

b. Faktor Psikologis

Faktor psikologis dapat berupa pendorong aktifitas belajar itu. pendorong aktivitas belajar yang memiliki pengaruh besar dalam belajar anak-anak adalah cita-cita.

\section{Konsep Remaja}

Menurut Hurlock (1980: 206), kata remaja atau adolescence berasal dari bahasa Latin adolescere yang berarti tumbuh atau menjadi dewasa. Masa remaja merupakan salah satu fase dalam kehidupan manusia, dimana pada masa ini terjadi suatu peralihan dari masa anakanak menuju masa dewasa. Berbagai gejolak perubahan pun terjadi di dalam kehidupan seseorang ketika memasuki usia remaja karena untuk mempersiapkan diri menuju masa dewasa seperti perubahan biologis, psikologis maupun perubahan sosial. Kondisi ini mengakibatkan terjadinya berbagai disharmonisasi yang membutuhkan penyeimbangan sehingga remaja dapat mencapai taraf perkembangan psikososial yang matang dan adekuat sesuai dengan tingkat usianya.

Pada masa remaja, individu mengalami berbagai perubahan, baik fisik maupun psikis. Selain itu remaja juga berubah secara kognitif dan mulai berpikir abstrak seperti orang dewasa, Pada periode ini pula remaja mulai melepaskan diri secara emosional dari orang tua dalam rangka menjalankan peran sosialnya yang baru sebagai orang dewasa (ClarkeStewart \& Freedman, 1987, Ingersoll, 1989) dalam Agustiani (2006). Umumnya, dalam masa remaja terjadi proses belajar 


\begin{tabular}{|c|c|c|c|c|}
\hline Prosiding & e ISSN : 2581- & & & \\
Penelitian \& & Vol 6, No: 2 & Hal: $123-180$ & Juli 2019 \\
$\begin{array}{c}\text { Pengabdian } \\
\text { Kepada }\end{array}$ & 1126 p ISSN : & 2442-448X & & \\
Masyarakat & & & \\
\hline
\end{tabular}

menyesuaikan diri dengan standard dan kebiasaan kelompok. Semua perubahan yang terjadi di dalam diri pada masa ini menuntut individu untuk melakukan penyesuian, menerima perubahan itu sebagai bagian dari dirinya, dan membentuk "sense of self" yang baru tentang siapa dirinya, untuk mempersiapkan diri menghadapi masa dewasa.

Secara umum, masa remaja terbagi menjadi tiga bagian, yaitu:

a. Masa remaja awal (12-15 tahun)

Pada masa ini individu mulai meninggalkan peran sebagai anak-anak dan berusaha mengembangkan diri sebagai individu yang unik dan tidak tergantung pada orang tua. Fokus dari tahap ini adalah penerimaan terhadap bentuk dan kondisi fisik serta adanya konformitas yang kuat dengan teman sebaya.

b. Masa remaja pertengahan (15 -19 tahun)

Masa ini ditandai dengan berkembangnya kemampuan berpikir yang baru. Teman sebaya masih memiliki peran yang penting, namun individu sudah lebih mampu mengarahkan diri sendiri (selfdirected).

c. Masa remaja akhir (19-22 tahun).

Masa ini ditandai oleh persiapan akhir untuk memasuki peran-peran orang dewasa. Selama periode ini remaja berusaha memantapkan tujuan vokasional dan mengembangkan sense of personal identity.

\section{PEMBAHASAN}

Dengan melihat dari pendahuluan yang menguraikan mengenai fenomena yang terjadi dari dampak perginya seorang ibu yang menjadi TKW terhadap penurunan prestasi belajar remaja, anak berada di lingkungan sosial yang kurang memperhatikan akan kebutuhan belajar pada anak. Seperti lingkungan keluarga, orang tua yang tidak memperhatikan kebutuhan-kebutuhan yang diperlukan oleh anak untuk belajar, lingkungan teman sebaya yang membawa pengaruh tidak baik kepada anak sehingga anak cenderung mengikuti pergaulan tersebut daripada harus belajar dan lingkungan sekolah yang selalu melakukan penekanan pada sistem belajar sehingga anak menjadi malas untuk belajar karena dianggap 'terlalu mengekang' dirinya. Dari lingkungan sosial tersebut dapat disimpulkan bahwa anak kurang menyukai hal-hal yang dianggap mengisolasi dirinya, karena pada usia remaja anak cenderung menginginkan sesuatu yang membuatnya senang dan juga selalu penasaran dengan hal-hal yang baru diluar kegiatan belajar.

Melihat hal tersebut, ternyata terdapat beberapa faktor yang menyebabkan penurunan prestasi belajar pada remaja. Adapun faktor yang menyebabkan prestasi belajar remaja menjadi menurun adalah sebagai berikut:

1) Faktor-faktor yang berasal dari luar diri seseorang, yang dapat digolongkan lagi dalam dua golongan:

c. Faktor-faktor non-sosial

Pada faktor ini orang tua kurang memperhatikan kebutuhan perlengkapan belajar anak sehingga anak cenderung akan menjadi malas untuk belajar karena tidak didukung dengan perlengkapan belajar yang memadai dari orang tua.

d. Faktor-faktor sosial

Pada faktor ini, orangtua kurang dalam melakukan pendampingan kepada anak ketika anak ingin belajar, sehingga tidak ada yang yang memberikan contoh untuk belajar kepada anak. Kemudian keluarga TKW tersebut tidak hanya memiliki satu orang anak saja, sehingga orang tua tidak hanya memikirkan pendampingan belajar pada anaknya yang sudah berusia remaja saja, melainkan harus mengurus anak-anaknya yang lain juga. Hal ini pun dapat menyebabkan anak yang telah berusia remaja kurang memiliki semangat dalam belajar.

2) Faktor-faktor yang berasal dari dalam pembelajar, dan juga dapat lagi digolongan menjadi dua yaitu:

a. Faktor Fisiologis 


\begin{tabular}{|c|c|c|c|c|}
\hline Prosiding & e ISSN : 2581- & & & \\
Penelitian \& & Vol 6, No: 2 & Hal: $123-180$ & Juli 2019 \\
$\begin{array}{c}\text { Pengabdian } \\
\text { Kepada }\end{array}$ & 1126 p ISSN : & 2442-448X & & \\
Masyarakat & & & \\
\hline
\end{tabular}

Pemenuhan kebutuhan dari orang tua kepada anak dikategorikan belum dapat terpenuhi secara penuh kepada anak contohnya pemberian nutrisi masih kurang. Padahal pemenuhan kebutuhan nutrisi yang baik kepada anak akan menambah kecerdasan pada anak terutama dalam pelajaran di sekolah. Namun lain halnya yang terjadi di keluarga TKW, orang tua tunggal yakni ayah kurang paham mengenai asupan nutrisi yang seharusnya dipenuhi dengan baik kepada anak.

b. Faktor Psikologis

Dalam hal ini, anak tidak memiliki seseorang yang dapat memacu semangatnya untuk belajar dikarenakan ayah yang juga sibuk bekerja ada yang sebagai buruh, maupun nelayan. Sehingga waktu yang diberikan kepada anaknya yang telah remaja tersebut dapat dikatakan kurang dan tidak dapat selalu memberikan motivasimotivasi belajar kepada anak.

\section{KESIMPULAN}

Ibu yang bekerja sebagai TKW tentu akan memberikan dampak, baik positif maupun negatif bagi dirinya dan terutama bagi keluarga yang ditinggalkan. Salah satu permasalahan dari ibu yang bekerja sebagai TKW bagi keluarga adalah penurunan prestasi belajar pada remaja. Turunnya prestasi belajar ternyata disebabkan oleh beberapa faktor yang mempengaruhinya seperti: (1) Faktorfaktor yang berasal dari luar diri seseorang yang terdiri dari faktor-faktor non-sosial dan faktor-faktor sosial; dan (2) Faktor-faktor yang berasal dari dalam pembelajar yang meliputi faktor fisiologis dan faktor psikologis.

Faktor-faktor tersebut memang dangat berkaitan dengan lingkungan dimana anak TKW tersebut berada. Lingkungan yang tidak mendukung dirinya dalam hal belajar tentu akan berpengaruh pada penurunan prestasi belajar pada anak, terutama teman sebaya yang membawa pengaruh besar bagi anak yang telah berusia remaja.

\section{DAFTAR PUSTAKA}

Anni, Catharina Tri, dkk. 2006. Psikologi Belajar. Semarang. UPT MKK.UNNES.

Hurlock, E.B. 1980. Psikologi Perkembangan, Jakarta: Erlangga

Suryabrata, Sumadi. 2008. Psikologi Pendidikan. Jakarta: RajaGrafindo Persada.

Puspitawati, H. (2011 ). Fungsi Pengasuhan dan Interaksi Dalam Keluarga Terhadap Kualitas Perkawinan dan Kondisi Anak Pada Keluarga Tenaga Kerja Wanita (TKW). Jur. IIm. Kel. \& Kons. Vol. 4 No. 1.

BNP2TKI. Data Penempatan dan Perlindungan TKI. Diakses pada 18 April 2018 pukul: 15.30 WIB.

http://www.bnp2tki.go.id/stat_penempatan /indeks

Data Dinas Ketenagakerjaan Indramayu. 2018. Permasalahan Perlindungan Pekerja Migran Indonesia (PMI) dan Penyelesainnya

Undang-Undang No. 13 Tahun 2003 tentang Ketenagakerjaan 